\title{
MENGINGAT DAN MENDEKATKAN KEMBALI NILAI-NILAI KEARIFAN LOKAL (PIIL PESENGGIRI) SEBAGAI DASAR PENDIDIKAN HARMONI PADA MASYARAKAT SUKU LAMPUNG
}

\author{
Masitoh *) \\ masitohstkipm64@gmail.com \\ Pendidikan Bahasa dan Sastra Indonesia \\ Universitas Muhammadiyah Kotabumi
}

\begin{abstract}
ABSRACT
This article presents about the study of remember and bring it back the local genius based on harmony education among Lampung ethnic society. The purpose of the study was to describe the noble values in local genius Lampung ethnic society regarding the activities of harmonious and peaceful life in the midst of multicultural society. The focus of the study was the philosophy of Lampung people, it was Piil Pesenggiri that had some values: Nemui Nyimah, Nengah Nyappur, Sakai Sambaian, and Juluk Adek/Adok. Those values were hold tight, become spirit, source identity self, dignity, the grandeur of life, etic code/moral (what is Good) in life of Lampung etnic society. This study were collected throught any research paper about Piil Pesenggiri. The results showed that Piil Pesenggiri could play a role in developing the awareness of the importance of group life and encourage cooperation to achieve commons goals.
\end{abstract}

Kata kunci: kearifan lokal, piil pesenggiri, masyarakat suku Lampung.

\section{A. PENDAhuluan}

Tulisan ini menginformasikan tentang spektrum pergaulan dan interaksi secara luas yang dianut oleh orang bersuku Lampung, yaitu Piil Pessinggiri yang di dalamnya terkandung nilai-nilai, seperti: Nemui Nyimah, Nengah Nyappur, Sakai Sambaian, dan Juluk Adek/Adok. Muzakki (2017:262) mengemukakan bahwa bagi orang bersuku Lampung, Piil Pesinggiri merupakan seperangkat norma, etika, dan tata nilai yang dapat digunakan untuk berinteraksi di tengah komposisi karakter sosial masyarakat Lampung yang memiliki banyak varian. Piil Pesenggiri juga berkaitan dengan jati diri dan kepribadian orang bersuku Lampung. Hal tersebut dapat dirujuk melalui pendapat Hadikusuma (2004:119) berikut ini.
“Tando nou ulun Lappung, wat pi'il pesinggiri, you balak pi'il ngemik maleu ngigau diri. Ulah nou bejuluk you beadek, iling mewari ngejuk ngakuk Nemui Nyimah ulah nou pandai you Nengah you Nyapur, nyubali jejamou, begawey balak, Sakai Sambaian".
(Tandanya orang Lampung, ada Piil Pesenggiri, dia berjiwa besar, mempunyai malu dan harga diri, bernama besar dan bergelar, suka bersaudara, beri memberi terbuka 
tangan, pandai, ramah, dan suka bergaul. Mengolah bersama pekerjaan besar dengan tolongmenolong).

Melalui uraian di atas, sekurangkurangnya dapat dideskripsikan bahwa karakter dan kepribadian masyarakat adat Lampung memiliki koherensi dengan citacita besar pendidikan harmoni, yakni menciptakan pola-pola kehidupan harmonis, damai, dan dinamis. Dinamika hidup damai tampak pada proses realisasi pembangunan yang sedang berjalan. Terlihat tidak hanya satu etnik yang dominan dalam proses ini, tetapi juga para pendatang yang berasal dari beragam etnik yang ada turut andil; berkontribusi, bahumembahu memajukan pembangunan di daerah Lampung. Sinergi yang terjalin ini merupakan kronologis perjalanan multikulturalis Lampung yang terkonstruksi sejak lama, bukan sesuatu yang tiba-tiba dan instan. Dengan bermodalkan budaya dan adat istiadat itu, para pendahulu orang Lampung telah mampu meretas tatanan kehidupan masyarakat harmonis dan damai. Idealnya, keberhasilan ini bisa menjadi parameter bagi generasi sekarang dan yang akan datang untuk dapat menciptakan kembali dialog tentang nilai-nilai kearifan lokal ke dalam realitas keberagaman yang ada.

Irianto dan Margaretha (2011:149) mengatakan bahwa nilai yang terkandung dalam Piil Pesenggiri dapat diolah menjadi modal budaya dan modal simbolik dalam ranah kontestasi dengan pendatang. Akan tetapi, menurutnya, Piil Pesenggiri perlu redefinisi dan nilai-nilainya disegarkan kembali (invensi). Nilai-nilai Piil Pesenggiri dalam hubungannya dengan multikultur dapat dijadikan modal hubungan antaretnis di Indonesia sehingga resistensi dapat dilakukan secara halus dan tanpa disadari konflik dapat dieliminasi.

Sejalan dengan itu, Nurdin (2009:94-95) mengatakan, Piil Pesenggiri merupakan acuan moral, etika, dan pandangan hidup dinamis yang mengandung nilai-nilai, ajaran moral yang merupakan jati diri yang terbuka untuk menjawab tantangan budaya asing yang cenderung negatif dalam proses transformasi sosial budaya. Di lain pihak, Yusuf (2016:172) juga mengemukakan, nilai-nilai atau filsafat hidup masyarakat Lampung khususnya beradat Pepadun, tidak bertentangan dengan nilai-nilai agama (Islam). Akan tetapi, diakui Yusuf (2016:181-182) bahwa pada taraf tertentu, dialektika antara nilai-nilai filsafat hidup dengan nilai-nilai agama (Islam) masih sering mengganggu kreativitas dan aktivitas kehidupan masyarakat Lampung. Hal ini berdampak pada falsafah hidup mereka yang dikenal dengan sebutan Piil Pesenggiri, menjadi terasingkan dari kehidupan masyarakat sehari-hari. Padahal, 
berbagai nilai dan filsafat hidup Piil Pesenggiri secara filosofis sesungguhnya koheren dengan nilai-nilai Islam dan bahkan juga relevan dengan nilai-nilai Pancasila.

Berpijak pada penjelasan di atas, artikel ini bertujuan untuk mengingatkan dan memperkenalkan kembali nilai-nilai dan falsafah hidup Piil Pesenggiri masyarakat adat Lampung sebagai upaya resolusi konflik horizontal yang terkadang terjadi di tengah masyarakat. Lebih dari itu, nilai-nilai luhur yang terkandung dalam falsafah hidup Piil Pesenggiri ini dapat dijadikan sebagai modal dan kemandirian budaya untuk membentuk formula pendidikan harmoni berbasis (local genius). Di tengah gelombang kemajemukan masyarakat Lampung, konflik berposisi bagaikan "bara dalam sekam" jika tersulut sedikit masalah, akan mudah terbakar dan menjadi bentuk kekerasan.

Beranjak dari femomena di atas, anasir kebudayaan masyarakat adat Lampung tampak sedang mengalami pergeseran nilai dan makna. Padahal, kebudayaan menjadi "hak paten" yang melekat dan diimplementasikan setiap individu, kelompok, dan masyarakat di dalam kehidupan sehari-hari. Kebudayaan merupakan aksi, kerja nyata, tindakan serta sikap, sehingga implikasi dari wujud kebudayaan adalah berkaitan dengan masa depan, kerja sama, sosial, dan perubahan organisasi.

Kebudayaan menurut Parson dalam Uhi (2016:72), sebagai pola nilai dan norma dominan yang menstruktur proses-proses tindakan sosial. Oleh karenanya, jika akar budaya serta nilai-nilainya tidak lagi menjadi acuan bertindak dan bersikapakibat terkontaminasi dan atau tereduksi, akan memunculkan partisi atau sekat bagi masing-masing kelompok. Keberlangsungan ini dikhawatirkan akan menimbulkan mata rantai yang hilang (missing link) terhadap pemaknaan budaya yang telah dikenalnya. Imbasnya, rasa kepercayaan (feeling confidence) yang telah tertanam akan luntur. Hal ini disebabkan nilai-nilai luhur yang ada dalam kearifan lokal, yang selama ini telah diyakini dapat dijadikan modal budaya sebagai "perekat" antara pribumi dan pendatang, dikesampingkan keberadaannya.

Menyikapi kondisi ini, Idrus (2007:392) dalam sebuah pernyataannya mengingatkan bahwa pada situasi dan kondisi demikian ini, hanya kemandirian budayalah yang dapat memengaruhi cara pandang seseorang dalam memahami dunia. Kuncinya, kembali pada sikap diri masingmasing, bagaimana menempatkan dan memosisikan nilai budaya yang telah ada. Jangan sampai kesadaran sistem ketahanan budaya lokal yang telah terbentuk sejak lama ini, dikesampingkan begitu saja 
sehingga mudah dipelintir, atau bahkan diarahkan pada ketahanan budaya global yang tidak jelas nilai manfaatnya bagi jati diri dan kepribadian masyarakat kita. Pada posisi ini, pertumbuhan dan perkembangan sistem nilai budaya yang ada, baik yang telah diterima dengan sadar maupun yang tidak, idealnya direfleksi kembali serta diaktualisasikan dalam kehidupan sehari-hari agar tidak mudah terombang-ambing di tengah benturan budaya lain.

B. NILAI-NILAI KEARIFAN LOKAL (PIIL PESENGGIRI) SEBAGAI DASAR PENDIDIKAN HARMONI PADA MASYARAKAT SUKU LAMPUNG

\section{Masyarakat Suku Lampung dan Nilai-}

Nilai Kearifan Lokal (Local Genius)

Dalam mengungkap bentuk kearifan lokal masyarakat suku Lampung, beberapa ahli menggunakan istilah local genius. Meski banyak istilah dan penyebutan tentang hal ini, secara garis besar memiliki subtansi yang sama. Kearifan lokal dapat dipahami sebagai gagasan-gagasan setempat (local) yang bersifat bijaksana, penuh kearifan, bernilai baik, yang tertanam dan diikuti oleh anggota masyarakatnya Nilai-nilai kearifan lokal (local genius) adalah produk budaya masa lalu yang mengandung nilai kebenaran, etika dan estetika, yang dijadikan pegangan dan pandangan hidup (way of life) secara terus-menerus oleh masyarakat. Local genius merupakan nilai positif dari perilaku manusia yang dirujuk dari bermacam sumber, baik nilai-nilai agama, adat istiadat, petuah nenek moyang maupun budaya setempat. Perilaku dan nilai-nilai positif ini terbangun secara orisinal, natural, dan berkelanjutan. Implikasinya adalah, dapat beradaptasi dan berinteraksi dengan alam serta lingkungan sekitarnya oleh komunitas tertentu. Sampai pada akhirnya, secara turun temurun, sikap, dan perilaku positif ini berkembang menjadi sebuah identitas dan budaya tersendiri.

Sebagaimana yang telah disinggung sebelumnya bahwa masyarakat adat Lampung telah memiliki bentuk nilai-nilai kearifan lokal (local genius) bernama Piil Pesenggiri. Bagi masyarakat adat Lampung, Piil Pesenggiri menjadi gagasan konseptual yang nyata-nyata hidup di masyarakat. Piil Pesenggiri adalah suatu gagasan ideal yang berlaku bagi masyarakat Lampung, Piil Pesenggiri merupakan prinsip dan harga diri. Piil adalah prinsip dan Pesenggiri adalah harga diri. Artinya, unsur-unsur Pesenggiri merupakan prinsip-prinsip yang apabila prinsip itu ditegakkan, harga diri seseorang dengan sendirinya akan baik atau prestise seseorang akan menjadi baik atau tinggi dengan melakukannya. Berkaitan dengan Piil Pesenggiri, Iskandar Syah (1999:2425) mengatakan sebagai berikut: 
"Piil Pesenggiri secara harfiah berarti perbuatan atau perangai manusia yang agung dan luhur di dalam nilai dan maknanya. Oleh karena itu, patut diteladani dan pantang untuk diingkari. Dalam dokumen literatur resmi, Piil Pesenggiri diartikan sebagai segala sesuatu yang menyangkut harga diri, perilaku, dan sikap hidup yang harus menjaga dan menegakkan nama baik, martabat pribadi maupun kelompok. Secara totalitas, Piil Pesenggiri mengandung makna berjiwa besar, mempunyai perasaan malu, rasa harga diri, ramah, suka bergaul, tolongmenolong, dan bernama besar".

Sementara itu, di lain pihak, Hadikusuma (2004:119-123) mengatakan, falsafah hidup Piil Pesenggiri merupakan nilai- nilai budaya kerja, yang terdiri atas: nilai- nilai produktif (Nemui Nyimah); nilai-nilai kompetitif (Nengah Nyappur); nilai-nilai kooperatif (Sakai Sambaian); dan nilai- nilai inovatif (Juluk Adek/Adok). Tidak hanya itu, Yusuf (2013: 117) berpendapat, secara esensial falsafah hidup Piil Pesenggiri bagi masyarakat adat Lampung, berkaitan dengan eksistensi manusia hubungannya dengan Tuhan, dengan sesama manusia, dan alam lingkungannya. Dengan demikian, falsafah hidup Piil Pesenggiri terus tumbuh dan berkembang dalam kesadaran masyarakat, baik berkaitan dengan kehidupan yang sakral maupun yang bersifat profan. Tidak hanya mengandung nilai kesamaan dan kebersamaan semata, tetapi juga falsafah ini mengandung unsur dan nilai-nilai ke-Tuhanan. Oleh karena itu, Piil Pesenggiri merupakan local genius yang terbentuk dari akumulasi pengetahuan dan kebijakan yang tumbuh berkembang dalam komunitas atau masyarakat adat Lampung, dalam hal ini merepresentasikan perspektif teologis, kosmologis, dan sosiologis.

Dalam lingkup kehidupan nyata, nilai-nilai kearifan lokal (local genius) adat Lampung sangat relevan dengan perubahan dan perwujudan tingkah laku individu dan masyarakat. Kebiasaan dan tingkah laku masyarakat yang disandarkan pada nilai luhur ini akan menjadi gaya hidup (life style) dan identitas tersendiri. Oleh karena itu, bagi orang Lampung, baik Pepadun maupun Saibatin-kemandirian budaya ini dapat diposisikan sebagai wasilah dan modal berharga untuk berinteraksi dengan sesama.

Lampung memiliki masyarakat multikultural sebab Provinsi Lampung berjuluk "Gerbang Sumetera" ini dihuni oleh beragam etnis dan suku, seperti; Lampung, Jawa, Minangkabau, Sunda, Bali, Batak, Bugis, Madura, dan Cina. Keberagaman yang ada di Lampung perlu disadari sebagai keniscayaan dan ketetapan. Suatu masyarakat multikultural, menurut Parekh yang dikutip Adi (2008:263), tidak dapat mengabaikan tuntutan keanekaragaman. Oleh karena itu, tidak hanya masyarakat adat Lampung yang 
bertugas menjaga "gawang" keberagaman tersebut, melainkan para pendatang pun berkewajiban dan bertanggung jawab menjaga keberagaman yang telah digariskan itu. Realitas keragaman (heterogenitas atau diversitas) masyarakat dan kebudayaan di Lampung harus diakui secara jujur, diterima dengan lapang dada, dikelola dengan cermat, dan dijaga dengan penuh rasa syukur serta tanggung jawab oleh seluruh elemen masyarakat yang ada.

Secara kodrati, keberlangsungan hidup bersama dan saling ketergantungan merupakan kebutuhan dasar (basic needs) manusia untuk bertahan hidup. Untuk dapat membangun masyarakat multikultural, menurut Mudzhar (2005:18-19). paling tidak diperlukan 3 (tiga) pilar utama, yaitu:

1. adanya para pengambil kebijakan publik yang adil dan mampu mengantisipasi dampak negatif yang akan ditimbulkan oleh kebijakan publik yang akan diambilnya;

2. adanya para pemimpin agama yang berwawasan kebangsaan yang luas dan lebih mengedepankan agama sebagai nilai daripada agama institusional;

3. adanya masyarakat yang berpendidikan dan rasional dalam menyikapi keragaman keagamaan (religious market) dan perubahan sosial.

Memang sudah menjadi kehendak Illahi, Lampung ditakdirkan memiliki keragaman agama, etnis, budaya, dan bahasa. Hal inilah yang kemudian disebut banyak orang, Lampung sebagai daerah multikultural. Kondisi ini patut disyukuri bersama. Akan tetapi, dalam spektrum yang luas, multikultural di daerah ini diibaratkan bagai pisau yang bermata dua. Di satu sisi menjadikan bangsa ini kaya akan khazanah kebudayaan, di sisi lain, rentan akan benturan, perselisihan, dan konflik. Oleh sebab itu, ketika melaksanakan hidup dan kehidupan di wilayah yang "serba" multikulutural, menurut Prihantoro (2016:186), perlu menilik dan meninjau kembali konsep the other (yang lain: orang lain, agama/bangsa/budaya lain)—supaya tidak diacuhkan atau dikesampingkan keberadaannya begitu saja. Pernyataan ini, secara tidak langsung melatarbelakangi munculnya konsep pendidikan harmoni. Dari sisi teori pengembangan pendidikan, peluang ilmiah ini dapat dikaji dan dikembangkan keberadaanya untuk dijadikan model atau formulasi pendidikan baru pada kawasan atau daerah yang beragam atau multikultural.

Meski untuk kali pertamanya, pendidikan harmoni merupakan istilah pendidikan yang popular di Indonesia bagian timur, khususnya di Provinsi Sulawesi Tengah. Akan tetapi, tidak menutup kemungkinan, model pendidikan ini akan bermanfaat bagi daerah lain. Membangun dan merawat harmoni (perdamaian) bukanlah pekerjaan yang 
ringan. Pengelolaannya membutuhkan durasi waktu yang panjang, memerlukan ketekunan dari para penggiatnya selama bertahun-tahun. Meski demikian, menurut Nursaid (2015:60), untuk mewujudkan hal ini paling tidak membutuhkan integrasi 3 (tiga) aspek, yaitu: tujuan bersama (mutual goals), pencapaian tujuan yang saling menguntungkan (mutual benefts from achieving goals), dan saling menguatkan identitas (mutual identity). Ketiganya mesti terkonstruk secara sistemik dan apik.

Akan tetapi, di antara ketiga aspek itu, mutual identity menjadi faktor dominan dan paling diprioritaskan. Menurut Johnson \& Johnson (dalam Nursaid 2015:61), mutual identity mengandung beberapa sikap yang perlu diupayakan agar senantiasa tumbuh dan berkembang dalam setiap diri manusia. Sikap itu meliputi: (1) peduli dan menyadari identitas budaya yang dimilikinya; (2) menghormati identitas budaya orang lain; (3) mengembangkan identitas budaya tinggi yang beragam; dan (4) menjadikan identitas budaya tinggi sebagai basis nilai dalam masyarakat plural.

Beberapa sikap di atas, "mendalangi" munculnya terminologi 'damai' dengan arti yang bervariatif antara satu budaya dan budaya yang lain, begitu juga dengan konteks implementasinya. Pada akhirnya pendidikan harmoni adalah terwujudnya sebuah kesadaran bahwa masyarakat sebagai komunitas yang sama dan berbeda, sama-sama sebagai makhluk ciptaan Tuhan untuk dihargai, dihormati, dan disayangi sebagaimana sifat Tuhan Yang Maha Pengasih dan Penyayang. Untuk itulah, diperlukan sebuah konstruk yang mapan agar cita-cita besar tersebut dapat terwujud.

Diskursus local genius masyarakat adat Lampung merupakan fenomena menarik untuk dikaji-terlebih jika dapat dijadikan sebagai sumbangsih pemikiran, kritik, dan saran dalam upaya memperkenalkan kembali pendidikan harmoni berbasis nilai-nilai kearifan lokal (local genius). Mengungkap nilai-nilai local genius orang Lampung secara komprehensif bukanlah hal yang mudah. Oleh karenanya, pada tahap ini dilakukan penelusuran pustaka dari beberapa artikel yang relevan.

Sebagaimana yang telah diuraikan terdahulu, Piil Pesenggiri merupakan martabat dan harga diri orang Lampung. Secara prinsip, Piil Pesenggiri merupakan satu kesatuan yang saling terhubung dan terintegrasi. Dengan demikian, martabat dan harga diri ini tidak akan tegak berdiri apabila tidak ditopang oleh prinsip dan fundamen yang lain. Menurut Ahmad Muzakki (2017:265) ketika mewawancarai Humaidi Elhudri (15 September 2015), tidak akan ada guna dan artinya, seorang paham dengan falsafah ini, tetapi tidak melaksanakan empat prinsip penyangga Piil Pesenggiri yang lainnya, yakni: Nemui 
Nyimah, Nengah Nyappur, Sakai Sambaian, dan Juluk Adek/Adok.

\subsection{Nemui Nyimah: Pola Komunikasi} Hangat dan Terbuka

Bagi orang Lampung, Nemui Nyimah merupakan prinsip penghargaan dan konsepsi tata nilai yang ditafsirkan sebagai wujud rasa kepedulian sosial, kesetiakawanan, dan nilai-nilai kemanusiaan (human interest) lainnya. Prinsip dan sikap di atas dapat ditujukan dan ditunjukkan kepada siapa pun yang datang (bertamu), asalkan niat tulus membangun dan mengembangkan daerah Lampung. Hal ini terbukti pada wujud sikap ramah dan mau menerima yang ditunjukkan kepada para kaum kolonis (baca; sebutan para transmigran di zaman Belanda) yang berasal dari Pulau Jawa pada saat itu. Wujud rasa keberterimaan dari masyarakat adat Lampung itu berupa kerelaan dan ketulusan dari masyarakat adat Lampung Buay Nuban saat menghibahkan sebagian tanah leluhurnya untuk dijadikan lahan garapan dan permukiman bagi saudara barunya yang berasal dari Jawa, (Muzakki, 2015:90).

Kronologi di atas memperlihatkan, masyarakat adat Lampung memiliki keluhuran perilaku, sikap, dan budi pekerti. Peristiwa tersebut mengandung nilai fundamen, yakni dalam konteks menolong dan "menerima tamu", mereka tidak pernah mempersoalkan latar belakang suku, agama, dan bahasa. Pelajaran ini mengisyaratkan jika masyarakat adat Lampung telah mengawali dan menunjukkan jati dirinya untuk dapat hidup berdampingan secara harmonis dengan siapa pun dengan setulustulusnya.

Dari hasil wawancara Ahmad Muzakki (23 September 2015) Hidayat Sanjaya mengatakan, "Masyarakat adat Lampung selalu terbuka dengan siapa saja. Kami tidak mau menutup diri, bahkan menolak tamu yang datang. Kami ingin memiliki banyak saudara, kawan, dan teman. Sikap keramahtamahan dan mau menerima orang lain tersebut adalah suatu bukti bahwa kami selalu berpegang teguh pada nilai-nilai filosofis, sebagaimana yang telah diwariskan nenek moyang kami."

Sementara itu, menurut Sarbini dan Khalik (2010:31), perilaku dan sikap ini selaras dengan makna Nemui Nyimah secara bahasa. Nemui berarti menerima tamu dan Nyimah berarti memberikan sesuatu tanpa pamrih—-kata ini dapat juga diartikan royal. Tampaknya, prinsip dan konsep Nemui Nyimah mendeskripsikan warna dan ciri khas mutual identity masyarakat adat Lampung yang terbuka, mau menerima, memegang prinsip tinggi, dan menghormati kepada siapa pun yang akan berkunjung dan dikunjungi. Dengan demikian, seseorang sudah dapat dikatakan Simah apabila dia telah mampu memberikan sesuatu kepada orang lain. 
Inilah salah satu sifat dan ciri khas orang Lampung, yaitu: rasa memiliki hutang budi.

Dalam konteks masyarakat Lampung yang multikultural, ditambah dengan era "dunia tanpa batas" (borderless world), menemukan dan mengembangkan kembali sikap-sikap yang terdapat dalam mutual identity adalah keniscayaan. Penemuan kembali nilai-nilai ini dapat dijadikan karakter dan modal dalam berkomunikasi secara luas. Aspek komunikasi menjadi kanal, sebagai pintu masuk mewujudkan tatanan masyarakat yang harmonis. Faktor utama yang memiliki kontribusi terhadap terciptanya perdamaian pada suatu masyarakat adalah saluran komunikasi yang efektif. Terdapat dua landasan untuk menciptakan integrasi suatu sistem sosial, yaitu: (1) suatu masyarakat yang terintegrasi di atas tumbuhnya konsensus di antara norma-norma kemasyarakatan yang bersifat universal dan fundamental; (2) karena bermacam-macam anggota masyarakat sekaligus menjadi anggota dari berbagai kesatuan sosial.

Berkenaan dengan itu, Nemui Nyimah merupakan prinsip-prinsip dalam berkomunikasi yang berhasil digali dari khazanah lokal genius adat setempat. Dalam taraf implementasi, Nemui Nyimah menjadi pengetahuan (knowledge), sekaligus keyakinan (conviction) bagi pelakunya, sehingga menjadi penuntun (guide) dan pedoman (orientation) dalam menjalani aktivitas kehidupan. Apabila nilai-nilai ini terinternalisasi dengan baik, tidak menutup kemungkinan akan lahir generasi-generasi tangguh, kuat, dan tanpa pamrih, yang dapat memikul tugas berat sebagai pencipta sistem integrasi sosial yang harmonis di tengah-tengah masyarakat.

Secara tekstual dan kontekstual, nilainilai karakter yang terkandung dalam falsafah Nemui Nyimah merupakan kemandirian budaya dari masyarakat adat setempat, sebagai pola komunikasi dan interaksi di tengah masyarakat. Terwujudnya pola dan saluran komunikasi yang efektif akan membuka peluang bagi anggota masyarakat untuk dapat berkontribusi bagi perkembangan masyarakatnya. Dengan menggunakan pola-pola komunikasi yang efektif ini, problematika yang muncul di tengah masyarakat dapat didiskusikan dan diselesaikan dengan baik. Sebaliknya jika saluran komunikasi yang ada "tersumbat", problematika yang sedang dihadapi dapat menimbulkan potensi ketidakharmonisan, akan muncul benih-benih perpecahan antaranggota masyarakat terutama pada masyarakat yang heterogen. Sekali lagi, Nemui Nyimah merupakan bentuk nilainilai kearifan lokal (local genius) masyarakat adat Lampung yang dapat dijadikan modal budaya, sebagai fondasi dalam membangun anatomi pendidikan 
harmoni di tengah masyarakat multikultural.

\subsection{Nengah Nyappur: Sikap Suka} Berbaur

Di tengah-tengah masyarakat multikultural, Muzakki (2017:265) mengemukakan bahwa Nengah Nyappur dapat bertindak sebagai jembatan penghubung antara tata nilai adat dan sikap toleransi yang tercermin dalam pergaulan sehari-hari orang Lampung. Sikap toleran ini dapat meminimalisasi bahkan mengeliminasi munculnya perbedaanperbedaan yang ada di tengah masyarakat sehingga hidup menjadi mudah dan bermakna.

Menyikapi hal di atas, Sarbini dan Khalik (2010:32) mengatakan bahwa Nengah; berada di tengah (khalayak), dan Nyappur berarti berbaur. Nengah Nyappur merupakan pola hidup bermasyarakat, tidak mengisolasi diri dari orang atau suku, maupun bangsa lain. Disebut Nengah Nyappur karena sikap suka bergaul, suka bersahabat, dan toleran antar- sesama.

"Nengah Nyappur adalah sikap dan tata nilai masyarakat adat Lampung dalam berinteraksi dengan cara membuka diri dengan masyarakat umum. Adapun tujuan dari Nengah Nyappur, yaitu agar berpengetahuan luas, ikut berpartisipasi terhadap segala sesuatu yang sifatnya positif_-baik dalam pergaulan dan kegiatan masyarakat yang dapat membawa kemajuan dan selalu bisa menyesuaikan diri terhadap perkembangan zaman" (Hasil Wawancara Ahmad Muzakki dengan Sihabuddin pada 25 September 2015).

Memperhatikan uraian di atas, Nengah Nyappur menggambarkan eksistensi masyarakat adat Lampung dalam berinteraksi dengan masyarakat lainya. Mereka lebih mengutamakan rasa kekeluargaan dan persahabatan dengan siapa saja-dengan tidak membedakan suku, agama, tingkatan, asal usul, dan golongan. Sebagai bentuk manifestasi dari nilai-nilai luhur, karakter yang melekat dalam Nengah Nyappur, dapat dijadikan sebagai modal budaya dalam membina hubungan yang baik di tengah masyarakat multikultural. Sikap luhur ini perlu ditularkan secara masif. Mengingat, interaksi sosial adalah kunci dari semua kehidupan sosial. Tanpa adanya interaksi sosial maka tidak akan mungkin ada kehidupan bersama.

Dalam konteks mewujudkan kehidupan multikultural yang harmonis, nilai-nilai luhur Nengah Nyappur perlu diterjemahkan dan diinternalisasikan secara masif pada lintas forum. Mulai dari yang bersifat formal, informal, dan nonformal hingga pada tingkatan struktur masyarakat yang ada. Pada proses interaksi sosial, Nengah Nyappur dapat dimaknai sebagai wujud dan bentuk kompetisi untuk mencapai kebaikan, tidak ada lawan, tetapi 
berlomba-lomba bekerja keras untuk mencapai prestasi yang baik. Sebab itulah, ditegaskan Fachruddin (2005, 16-18), dalam berkompetisi yang baik dibutuhkan tiga kemampuan pokok, yaitu: (a) kemampuan merumuskan gagasan; (b) kemampuan mengungkapkan gagasan dalam bentuk rencana strategi dan rencana operasional, serta (c) kemampuan mengevaluasi strategi dan operasional dimaksud di atas. Ketiga syarat ini sudah ada dalam Nengah Nyappur, konsep ini menggambarkan sebuah ajaran yang mirip dengan teori manajemen pengelolaan secara modern.

Keberadaan Nengah Nyappur bagi orang Lampung, setidaknya dapat dijadikan wasilah untuk membentuk karakter dan kepribadian kuat. Nengah Nyappur melambangkan sikap nalar yang baik, tertib, dan sekaligus juga dapat menjadi embrio dari kesungguhan untuk meningkatkan pengetahuan serta sikap adaptif terhadap perubahan. Konsep Nengah Nyappur dalam konteks kehidupan dan relasi sosia di tengah komunitas yang multikultural, memiliki kekuatan sebagai piranti pencipta suasana sosial yang kondusif. Olek karenanya, dengan memahami, mengangkat, dan menerapkan kembali konsepsi in idealnya dapat memberikan peran dan sumbangan bagi tertatanya hubungan sosial yang harmoni dengan semangat saling menghargai dan menghormati sesamanya.

\subsection{Sakai Sambaian: Prinsip Guyub Hati dan Solidaritas di Ranah Sosial}

Menurut Sihabuddin, dari hasil wawancara Muzakki (25 September 2015), Sakai Sambaian mengandung nilai saling tolong-menolong dan gotong-royong dalam bertetangga dan berkerabat, termasuk urusan dalam mengadakan upacara pernikahan dalam adat Lampung dan lain sebagainya. Sebagai produk nilai-nilai kearifan lokal, Sakai Sambaian merupakan konsepsi yang berupa hasil (output) dan tindakan nyata dari wujud jiwa sosial yang tinggi dari masyarakat adat Lampung. Sebagaimana dikatakan Bukri (dalam Sarbini dan Khalik (2010:33) bahwa Sakai Sambaian merupakan bentuk kewajiban seseorang untuk berjiwa sosial, gotong royong, berbuat baik dengan sesama manusia, dengan balas jasa atau pun tidak.

Berpijak pada penjelasan di atas, Sakai Sambaian merupakan bentuk nilainilai kearifan lokal (local genius) yang diterjemahkan ke dalam wujud perilaku dan tindakan nyata seseorang. Hal ini yang tidak hanya terbatas pada perihal adat Lampung semata, melainkan lebih luas dari itu. Tindakan yang dimaksudkan Sakai Sambaian adalah tolong-menolong, bahumembahu, dan saling memberikan sesuatu kepada pihak lain yang sangat memerlukan bantuan dan pertolongan. Menariknya, 
bentuk aplikasi pertolongan ini tidak hanya terbatas pada sesuatu yang bersifat material, melainkan juga dalam arti moral, termasuk sumbangan tenaga, pemikiran, dan lain sebagainya. Dengan demikian, Sakai Sambaian berarti tolong-menolong dan bergotong-royong, artinya memahami makna kebersamaan atau guyub. Eksistensi Sakai Sambaian hakikatnya menunjukkan rasa partisipasi serta solidaritas yang tinggi terhadap berbagai kegiatan pribadi dan sosial kemasyarakatan pada umumnya.

Selanjutnya, dalam ruang dan konteks bernegara, wujud nyata Sakai Sambaian selaras dengan ideologi Pancasila, yang secara jelas meniscayakan untuk bergotongroyong. Demikian halnya dengan adat Lampung, seseorang akan merasa kurang terpandang apabila tidak mampu berpartisipasi dalam suatu kegiatan kemasyarakatan yang ada di sekitarnya. Sikap dan karakter ini menggambarkan rasa toleransi kebersamaan. Oleh sebab itulah, mereka rela memberikan apa saja apabila pemberiannya memiliki nilai manfaat bagi orang atau anggota masyarakat lain yang membutuhkan. Etos Sakai Sambaian ini dapat diterjemahkan dan diinternalisasikan dengan baik secara bersamaan oleh Ulun Lampung dan para pendatang maka tidak mustahil akan menjadi bagian penting bagi terciptanya konstruk pendidikan harmoni di tengah masyarakat multikultural.

\subsection{Juluk Adek/Adok: Fadilat dan Keluhuran Budi Pekerti}

Juluk Adek/Adok merupakan sebuah gelar kehormatan secara adat yang diberikan kepada seseorang remaja atau dewasa yang telah mapan. Konteks mapan di sini tidak hanya dimaknai sebagai orang yang telah mampu atau kuasa secara materi semata. Akan tetapi, lebih dari itu, yakni apabila seseorang telah mampu mengaplikasikan,

mengejawantahkan, dan menginternalisasikan pilar-pilar penyangga sebelumnya (Nemui Nyimah, Nengah Nyappur, Sakai Sambaian). Sebagaimana dikatakan Abu Tholib Khalik Gelar Tuan Gusti Adat bahwa orang yang telah memiliki Bejuluk Beadek, tidaklah menjamin bahwa dia harus punya prestise di dalam masyarakat. Salah satu penyebab orang tersebut bernilai karena menjalankan faktor-faktor lainnya, seperti Neтиi Nyimah, Nengah Nyappur, dan Sakai Sambayan, (hasil wawancara Muzakkir, 2015).

Memperhatikan uraian di atas, Juluk Adek/Adok dapat dikatakan sebagai prestise dan keluhuran budi pekerti yang menjadi "pamungkas" seseorang setelah berkontribusi secara nyata dalam kehidupan bermasyarakat. Proses memperoleh gelar 
(adek/adok) tidaklah mudah, tetapi harus melewati tahap dan syarat tertentu setelah memperoleh prestasi. Maksudnya, seseorang telah melakukan perubahan yang urgen dalam kehidupan manusia, seperti pencanangan idealisme atau cita-cita dan tercapainya cita-cita yang luhur di tengah masyarakat. Setelah tahapan itu terlaksana, peristiwa semacam ini tidak dapat dibiarkan begitu saja, harus diperingati dan diberi hadiah berupa gelar kehormatan secara adat. Dasar inilah yang kemudian Juluk Adek/Adok ditafsirkan dengan makna inovatif. Biasanya, inovasi yang dilakukan bersifat terus-menerus; antara idealisme hingga menjadi sebuah realita. Berdasarkan realita atau cita-cita yang telah diraihnya itu maka dia berhak mendapatkan Juluk Adek/Adok.

Terwujudnya gelar adat seseorang harus dibarengi dengan perjuangan dalam meningkatkan kesempurnaan diri, hidup tertib, dan memiliki tata krama. Kesemua ini akan dapat terwujud apabila telah mempraktikkan nilai-nilai yang terkandung dalam Nemui Nyimah, Nengah Nyappur, dan Sakai Sambaian. Dalam realitas sosial, tata krama seseorang akan menjadi indikator dan penilaian orang terhadap diri seseorang. Apabila seseorang mengabaikan ketiga prinsip tersebut, akan sulit untuk mendapatkan gelar atau Juluk Adek/Adok.

Menindaklanjuti hal di atas, penyematan gelar adat (Juluk Adek/Adok) tidaklah terjadi secara tiba-tiba. Seseorang hendaknya telah memiliki konsep kesempurnaan diri, memiliki tata krama dan berpegang teguh pada titie gemati adat atau hidup tertib. Dengan kata lain, indikator kesempurnaan diri bagi Ulun Lampung adalah manakala dia telah mampu menginternalisasikan konsep Nemui Nyimah, Nengah Nyappur, dan Sakai Sambaian dalam kehidupan sehari-hari di tengah masyarakat yang majemuk.

\section{Piil Pesenggiri: Jantung Pendidikan} Harmoni Berbasis Nilai-nilai Kearifan

\section{Lokal}

\section{(Local Genius)}

Menggagas pendidikan harmoni berbasis nilai-nilai kearifan lokal (local genius) bukanlah suatu perkara yang mudah. Muzakki (2017:95) mengatakan, suku dan etnis yang ada di Lampung masing-masing telah memiliki bentuk dan jenis local genius-nya sendiri. Namun, dengan meminjam istilah Johnson \& Johnson, penguatan identitas menjadi titik tekan dalam menumbuhkan pendidikan harmoni. Mengapa? Oleh karena di dalam penguatan berpendar sikap-sikap positif yang senantiasa perlu diupayakan agar tumbuh berkembang pada setiap manusia. Adapun salah satu sikap positif yang mesti dikembangkan adalah sikap menjadikan identitas budaya tinggi sebagai basis nilai dalam masyarakat plural. Identitas budaya 
itu dengan sendirinya dapat bertindak sebagai identitas komunikasi dari sistem perilaku verbal dan nonverbal, yang memiliki arti dan yang dibagikan di antara anggota kelompok, yang memiliki rasa saling memiliki dan yang membagi tradisi, warisan, bahasa, dan norma-norma yang sama.

Sejalan dengan itu, konstruksi budaya dan nilai-nilai budaya lokal Piil Pesenggiri memiliki urgensi sebagai simbol dan identitas masyarakat adat Lampung. Mestinya, nilai-nilai ini menjelma dalam karakter dan kepribadian sebagai identitas komunikasi bagi setiap individu yang ada. Oleh karena itu, dengan sendirinya, simbol dan identitas ini akan menjadi "pakem", penuntun, dan penghubung bagi masyarakat adat dalam berinteraksi. Konstruksi budaya dan kearifan lokal semacam ini dipercayai dan diakui sebagai elemen penting yang mampu mempertebal kohesi sosial di antara warga masyarakat. Dengan demikian, local genius dapat menjadi basis dan tata kelola menciptakan pendidikan harmoni bagi masyarakat.

Proses pendidikan harmoni berbasis local genius merupakan upaya berkelindan dua unsur sekaligus, yaitu unsur pendidikan dan kebudayaan. Di satu sisi, pendidikan bertugas mentransformasikan sistem sosial budaya dari satu generasi ke generasi yang lain. Sementara di sisi lain, di tengahtengah masyarakat telah terdapat konsepsi- konsepsi nilai yang hidup di alam pikiran sebagian besar masyarakatnya, yang sekaligus berfungsi sebagai pedoman tertinggi bagi sikap mental, cara berpikir, dan tingkah laku manusia. Secara bersama kedua aspek ini menegaskan bahwa di mana ada pendidikan, di situ kebudayaan menyertainya. Oleh sebab itu, tidak ada kebudayaan tanpa pendidikan dan begitu pula praksis pendidikan selalu berada dalam lingkup kebudayaan.

Dalam konteks masyarakat adat Lampung, Piil Pesenggiri memiliki ruang yang seluas-luasnya untuk menciptakan pendidikan harmoni. Piil Pesenggiri; Nemui Nyimah, Nengah Nyappur, Sakai Sambaian, dan Juluk Adek/Adok dapat menjadi modal budaya dan "denyut jantung" bagi terwujudnya harga diri dan martabat. Jika hal ini terpenuhi, dengan sendirinya seseorang akan menjadi sempurna (baca; insan kamil) yang memiliki produktivitas di bidangnya masing-masing, memiliki daya saing yang sangat tinggi, mampu melaksanakan kerja sama yang baik, kooperatif, dan menemukan inovasi-inovasi baru. Sebagai produk local genius masyarakat adat Lampung, Piil Pesenggiri mengandung inti ajaran nilai-nilai sosial (social values), etika atau moralitas (morality values), dan nilai keagamaan (relegious values).

Keberadaan dan posisi Piil Pesenggiri sebagai falsafah hidup bagi tuan rumah 
(Ulun Lampung)—semestinya dapat diolah untuk menjadi sumber keunggulan dan kekuatan yang dinamis dengan keunikannya di tengah pergumulan masyarakat multikultural. Sebagai bentuk mutual identity, Piil Pesenggiri dapat menjadi "pondasi" pendidikan harmoni yang berbasiskan kelokalan. Hal ini disebabkan, falsafah ini dapat memainkan peranannya sebagai katalisator dan filter untuk menyaring budaya-budaya yang datang dari luar yang tidak sesuai dengan kepribadian bangsa ini.

Semestinya, budaya asing yang datang tidak semua harus diterima glondongan, tetapi perlu "dinetralisasi" dulu menggunakan "piranti” local genius yang telah ada. Secara perlahan, fokus transfer nilai dari Piil Pesenggiri dapat menciptakan serta meredefinisi proses pemanusiaan manusia (humanisasi), yang lebih berorientasi pada terbentuknya individu yang mampu memahami realitas dirinya dan masyarakat sekitarnya yang beragam, multi etnik, dan multikultural.

3. Nilai-nilai Kearifan Lokal (Local Genius): Peluang atau Tantangan

Bagi masyarakat multikultural modern, keberadaan local genius kian hari kian mengkhawatirkan, berada dalam ruang ketidakpastian, terpojokkan, dan terpinggirkan. Eksistensi local genius seolah telah kalah dengan budaya global dan modern. Oleh sebab itu, banyak yang beranggapan "miring", jika local genius sesuatu yang kuno dan tidak relevan lagi dengan konteks kekinian. Sikap demikian semakin menjadikan posisi local genius tidak atau belum "tergarap" secara maksimal. Dampaknya, keluhuran nilainilai local genius ini tidak mampu membumi, sekaligus menjadi kesadaran bersama di tengah masyarakat multikultural.

Berkenaan dengan hal di atas perlunya ikhtiar dari seluruh komponen masyarakat untuk merefleksi dan melakukan penemuan kembali terhadap nilai-nilai luhur budaya bangsa atau revitalisasi-atau semacam tradisi yang diciptakan melalui gerakan nasionaldengan melibatkan seluruh komponen sebagai konsensus yang lahir dari kesadaran nasional. Pernyataan ini menjadi "cambuk" agar selalu menilik dan memperhatikan kondisi local genius yang telah diwariskan oleh nenek moyang kita. Idealnya, nilainilai luhur yang ada di negara kitatermasuk di dalamnya nilai-nilai Piil Pesenggiri masyarakat adat Lampungsecara sadar dan yakin dapat terimplementasikan secara baik di tengah masyarakat multikultural.

Menindaklanjuti pernyataan di atas, Eko dan Tijan (2010:3) membeberkan formulasi strategi dan upaya yang tepat untuk digunakan menghadapinya, yaitu dengan cara menguji kembali premis- 
premis dan nilai-nilai budaya lama melalui bentuk-bentuk pendidikan. Memperhatikan hal ini maka upaya dan strategi menemukenali kembali nilai-nilai budaya merupakan keniscayaan yang harus segera diwujudkan di era modern ini. Mengingat, banyak upaya pelemahan yang dilakukan dengan berbagai cara dan metode terhadap sistem ketahanan budaya lokal secara masif. Penyampingan dan upaya pelemahan nilainilai kearifan lokal dapat memengaruhi kesadaran berbudaya kita. Hal ini membuat posisi budaya dan nilai-nilainya semakin lemah, terpojokkan, dan terpinggirkan. Padahal, menurut Talcott yang dikutip Malihah (2010:181), nilai-nilai kebudayaan dapat menjiwai kepribadian dan mempengaruhi struktur kebutuhan, dapat menentukan kehendak seseorang atau kelompok dalam menerapkan peranan sosialnya.

Pembumian kembali nilai-nilai luhur local genius di tengah masyarakat heterogen dan multikultural memiliki energi positif. Menurut Haba yang dikutip Abdullah (2008:34-35), kearifan lokal dapat menyediakan piranti yang cukup lengkap, yaitu: berupa aspek kohesif yang terdiri atas elemen perekat lintas agama, lintas warga, dan kepercayaan. Selain itu, kearifan lokal dapat juga memberikan warna kebersamaan bagi sebuah komunitas dan berfungsi mendorong terbangunnya kebersamaan, apresiasi, sekaligus sebagai sebuah mekanisme bersama untuk menepis berbagai kemungkinan yang dapat meredusir, bahkan merusak solidaritas komunal, yang dipercaya berasal dan tumbuh di atas kesadaran bersama, dari sebuah komunitas yang terintegrasi.

Kiranya, dalam konteks masyarakat multikultural, perlu ada upaya dari masingmasing kelompok etnik untuk secara legowo merevitalisasi budaya etniknya agar mampu menyerap nilai-nilai eksternal universal; seperti demokrasi, perdamaian, kontekstual dengan kondisi struktur sosial, ekonomi, politik, dan budaya. Dengan demikian, dalam perspektif multikultural masyarakat Lampung_etnik Lampung maupun etnik-etnik lainnya yang ada di Lampung, dapat mengapresiasi gagasan komunitas bayangan tersebut sehingga tidak akan terjadi lagi pengesampingan nilai-nilai kearifan lokal (local genius), norma, dan agama dari masing-masing etnis yang ada. Akhirnya, di tengah masyarakat Lampung yang multikultural, tidak lagi tumbuh sikap subjektivitas dan sikap ekslusivitas. Sadar atau tidak, munculnya kedua sikap ini, sekaligus dipupuk dan ditambah dengan budaya yang bersumber pada globalisasi; seperti gaya hidup konsumtif dan individualis-hedonis, akan mengganggu harmoni dan interelasi sosial masyarakat yang telah terbina sejak lama.

\section{SIMPULAN}


Pendidikan harmoni berbasiskan nilai-nilai kearifan lokal (local genius) dalam konteks masyarakat adat Lampung dapat ditemukan di dalam falsafah Piil Pesenggiri. Sebagai bentuk harga diri dan martabat, idealnya, Piil Pesenggiri selalu melekat sejak dari lahir hingga meninggal dunia. Bagi Ulun Lampung, Piil Pesenggiri dapat berperan sebagai penggerak dalam menumbuhkembangkan kesadaran akan arti penting hidup berkelompok dan mendorong kerja sama untuk mencapai tujuan bersama. Piil Pesenggiri dapat dijadikan modal budaya untuk membangun karakter masyarakat Lampung secara keseluruhanterutama dalam tujuan membangun warga negara yang memiliki kesadaran hidup bermasyarakat yang multikultural. Dalam konteks masyarakat multikultural, nilai luhur Piil Pesenggiri dapat diidentifikasi sebagai sumbangsih pemikiran dalam upaya memperkenalkan kembali pendidikan harmoni berbasis local genius. Hal ini disebabkan, falsafah Piil Pesenggiri terkandung 4 (empat) pilar yang saling berkelindan, yaitu: Nemui Nyimah, Nengah Nyappur, Sakai Sambaian, dan Juluk Adek/Adok. Keempat nilai-nilai tersebut adalah pilar dan sendi-sendi Ulun Lampung dalam bermasyarakat. Nilai-nilai falsafah hidup Piil Pesenggiri Ulun Lampung menggambarkan sebuah komunitas yang cinta damai. Dengan demikian, membumikan kembali produk nilai-nilai kearifan lokal (local genius) dapat dijadikan media pendidikan harmoni yang bersifat kohesif sebagai elemen perekat lintas agama, lintas warga, dan kepercayaan.

\section{DAFTAR RUJUKAN}

Abdullah, Irwan, ed. 2008. Agama dan Kearifan Lokal dalam Tantangan Global: Revitalisasi Kearifan Lokal (Studi Resolusi Konflik di Kalimantan Barat, Maluku, dan Poso).Yogyakarta: Pustaka Pelajar.

Eko,Handoyo dan Tijan. 2010. Model Pendidikan Karakter Berbasis Konservasi: Pengalaman Universitas Negeri Semarang. Semarang: Widya Karya Press.

Fachruddin, and Haryadi. 1996. Falsafah Piil Pesenggiri sebagai Norma Tatakrama Kehidupan Sosial Masyarakat Lampung. Bandar Lampung: CV. Arian Jaya.

Hadikusuma, Hilman. 2004. Masyarakat dan Adat Budaya Lampung. Bandung: Mandar Maju.

Idrus, Muhammad. 2007a,b. "Makna Agama dan Budaya bagi Orang Jawa". Dalam Jurnal UNISIA Vol. XXX (66): 392 
Irianto, Sulistyowati, dan Risma Margaretha. 2011. "Piil Pesenggiri: Modal Budaya dan Strategi Identitas Lampung". Dalam Jurnal Makara Sosial Humaniora 15 Vol.(2): 149

Iskandar Syah. 1999. Sejarah Kebudayaan Lampung. Lampung: Universitas Lampung. Malihah, Elly. 2010. "Membangun Sinergi Positif dalam Masyarakat Multikultural”. Dalam Jurnal Sekretariat Negara RI, No. 16: 181

Mudzhar, M. Atho. 2005. Pengembangan Masyarakat Multikultural Indonesia danTantangan ke Depan (Tinjauan dari Aspek Keagamaan dalam Meretas Wawasan \& Praksis Kerukunan Umat Beragama di Indonesia). Jakarta: Badan Litbang dan Diklat Keagamaan Puslitbang Kehidupan Beragama Depag RI.

Muzakki, Ahmad. 2015. Rekam Jejak Menyusun Riwayat Kota: Sebuah Kajian Etnografi Menemukenali Geneologi Kota Metro. Metro: Dinas Pendidikan Pemuda dan Olahraga (Disdikpora) Kota Metro Lampung.

Muzakki, Ahmad. 2017. Memperkenalkan Kembali Pendidikan Harmoni Berbasis Kearifan Lokal pada Masyarakat Adat Lampung. Dalam Jurnal Penamas Vol 3. (2): 262—265

Nursaid. 2015. "Integrasi Nilai Harmoni dalam Pendidikan Islam Melalui Keluarga dan Sekolah". Dalam Jurnal Palastren, Vol. 8 (1): 60-61

Parekh, Bikhu. Tanpa Tahun.Retinking Multiculturalism: Keberagaman Budaya dan Teori Politik. Diindonesiakan oleh Bambang Kukuh Adi. 2008.Yogyakarta: PT Kanisius.

Prihantoro, Hijrian A. 2016. “Tekstur Baru Studi Islam: Prototipe Dialektika Agama dan Realita”. Dalam Jurnal Millah, Vol. XV (2): 186

Sarbini, Abdurrahman dan Abu Tholib Khalik. 2010. Budaya Lampung: Versi Adat Megou Pa' Tulangbawang. Yogyakarta: Badan Penerbitan Filsafat UGM.

Uhi, Jannes Alexander. 2016. Filsafat Kebudayaan: Konstruksi Pemikiran Cornelis Anthonie van Peursen dan Catatan Reflektifnya. Yogyakarta: Pustaka Pelajar.

Yusuf, Himyari. 2013. Filsafat Kebudayaan, Strategi Pengembangan Kebudayaan Berbasis Kearifan Lokal. Bandar Lampung: Harakindo Publishing. 